\title{
RESPON EKSPLAN PISANG KLUTUK (Musa paradisiaca L.) TERHADAP KONSENTRASI EKSTRAK BIJI PINANG MUDA DAN AIR KELAPA MUDA SECARA IN VITRO
}

\section{Response of Klutuk Banana Explant (Musa paradisiaca L.) to Concentration of Young Areca Seed Extract and In Vitro Young Coconut Water}

\author{
Zulkifli dan Selvia Sutriana \\ Program studi Agroteknologi Fakultas Pertanian Universitas Islam Riau \\ Email: zulkifli@agr.uir.ac.id \\ [Diterima: Oktober 2019; Disetujui: November 2019]
}

\begin{abstract}
Nurseries play an important role in banana development. The tissue culture technique is an alternative to produce quality seeds in large quantities, uniform and produced in a short time and free of pathogens. Areca nut extract is an organic material that contains tannin and can replace bicycling used as a disinfectant in tissue culture activities. Coconut water is a food reserve that contains vitamins and growth substances, so it can stimulate germination. The purpose of the study was to examine the interaction and single response of klutuk banana explants to the concentration of areca nut extract and young coconut water in vitro. This research was carried out at the Biotechnology Laboratory, Faculty of Agriculture, the Islamic University of Riau with the planting material used Pisang Klutuk weevil with the method used in a factorial Completely Randomized Design (CRD) with $4 \times 4$. The first factor was seed extract Young areca nut and the second factor was Young Coconut Water. The parameters observed were the percentage of live explants, the percentage of contaminated explants, the age of shoot emergence, and the number of shoots. The observation results were analyzed statistically and continued with the further test of Honest Significant Difference (HSD) at the 5\% level. It was found that the best treatment was P2K2 (20\% young betel nut extract $(200 \mathrm{ml}+800 \mathrm{ml}$ distilled water) and young coconut water $20 \mathrm{ml} /$ liter media), where the percentage of life was $100 \%$, the percentage of contamination was $0 \%$, the age of shoots appeared was 37.67 days, and the number of shoots was 5 strands.
\end{abstract}

Keywords: Young Coconut Water, Young Areca Extract, Tissue Culture, Growth

\begin{abstract}
ABSTRAK
Pembibitan mempunyai peranan penting dalam pengembangan pisang. Teknik kultur jaringan merupakan alternatif untuk menghasilkan bibit bermutu dalam jumlah banyak, seragam, dan dihasilkan dalam waktu singkat serta bebas pathogen. Ekstrak biji pinang merupakan bahan organik yang mengandung tannin dan mampu menggantikan bayclin yang dipakai sebagai bahan desinfiktan pada kegiatan kultur jaringan. Air kelapa sebagai cadangan makanan yang mengandung vitamin dan zat tumbuh, sehingga dapat menstimulir perkecambahan. Tujuan penelitian untuk melihat respon secara interaksi maupun tunggal eksplan pisang klutuk terhadap konsentrasi ekstrak biji pinang dan air kelapa muda secara In vitro. Penelitian ini dilaksanakan di Laboratorium Bioteknologi Fakultas Pertanian Universitas Islam Riau dengan bahan tanam yang digunakan bonggol Pisang Klutuk dengan Metode yang digunakan Rancangan Acak Lengkap (RAL) faktorial dengan 4 x 4 faktor pertama adalah Ekstrak Biji Pinang muda dan faktor kedua adalah Air Kelapa Muda. Parameter yang diamati adalah persentase ekplan hidup, persentase eksplan terkontaminasi, umur muncul tunas, jumlah tunas. Hasil pengamatan dianalisis secara statistik dan dilanjutkan dengan uji lanjut Beda Nyata Jujur (BNJ) taraf 5\%. Hasil penelitian menunjukkan bahwa perlakuan terbaik P2K2 (pada ekstrak biji pinang muda $20 \%$ (200 $\mathrm{ml}+800 \mathrm{ml}$ aquades) dan air kelapa muda $20 \mathrm{ml} /$ liter media), dimana persentase hidup $100 \%$, persentase terkontaminasi $0 \%$, umur muncul tunas 37,67 hari, dan jumlah tunas 5 helai.
\end{abstract}

Kata kunci: Air Kelapa Muda, Ekstrak Pinang Muda, Kultur Jaringan, Pertumbuhan 


\section{PENDAHULUAN}

Indonesia sebagai negara tropis yang kondisi lahan dan lingkungan cocok untuk budidaya pisang (Musa paradisiaca. L), peluang untuk mengembangkan dalam skala agribisnis yang berorientasi pasar ekspor. Pisang juga mempunyai potensi besar sebagai bahan baku olahan (Dodik dan Lety, 2008). Pisang mengandung $68 \%$ air, $25 \%$ gula, $2 \%$ protein, $1 \%$ lemak dan minyak dan $1 \%$ serat selulosa (Parmathic, 2013). Pisang kaya mineral seperti kalium, magnesium, dan besi. Bila dibandingkan dengan jenis makanan nabati lain, mineral pisang hampir 100 persen dapat diserap tubuh. Berdasarkan berat 100 gram buah pisang mengandung vitamin B 6 sebanyak $0,5 \mathrm{mg}$ dan juga mengandung vitamin lain berupa vitamin A dan D. Peluang tersebut mendorong pisang untuk dikembangkan secara luas.

Pisang adalah tanaman yang memiliki fungsi ganda buahnya mengandung gizi yang merupakan sumber vitamin, mineral dan karbohidrat. Kulit pisang dapat dimanfaatkan untuk membuat cuka melalui proses fermentasi alkohol dan asam cuka. Daun pisang dipakai sebagai pembungkus berbagai macam makanan trandisional Indonesia (Pisang Klutuk). Daun pisang bila dipakai bahan pembungkus memiliki keistimewaan dimana hasil bungkusan menimbulkan aroma lebih harum dan makanan tidak cepat busuk, bila dibandingkan dengan menggunakan kertas maupun bahan dari plastik. Daun pisang banyak yang memerlukan mulai dari rumah makan sampai pedagang sate. Pisang Klutuk jenis pisang yang mampu menghasilkan daun yang cukup banyak dan daun tersebut tidak mudah robek. Untuk itu pisang ini sangat cocok dikembankan untuk mengambil daunnya. Batang pisang mampu menyimpan air dalam jumlah yang banyak hingga mampu mensuplai air lewat akar saat terjadi kekeringan sehingga tepat tanaman ini untuk dikembangkan pada lahan gambut yang kondisinya terbuka di musim kemarau. Fungsi lain secara tradisional air umbi batang pisang dimanfaatkan sebagai obat disentri dan pendarahan usus besar sedangkan air batang pisang digunakan sebagai obat sakit kencing dan penawar racun (Abdurrahman, 2011).

Pembibitan merupakan peranan penting dalam pengembangan pisang, pengembangan pisang dari suatu jenis pisang sacara tidak langsung akan mempengaruhi jumlah bibit yang akan disediakan (Asnin, 2010). Saat ini bibit yang ditanam petani berasal dari anakan pohon induk, sehingga jumlah anakan terbatas dan sulit mendapatkan bibit yang bebas serangan penyakit layu Fusarium maupun bakteri, apa lagi pisang klutuk memiliki anak yang sedikit dan bahkan banyak pula rumpun yang tidak memiliki anak sama sekali.

Teknik kultur jaringan merupakan alternatif untuk menghasilkan bibit yang bermutu dalam jumlah banyak, seragam, dan dihasilkan dalam waktu singkat. Kultur jaringan merupakan suatu teknik untuk mengisolasi bagian dari tanaman seperti titik tumbuh, organ, sekelompok sel atau bahkan sel, serta menumbuhkannya dalam lingkungan aseptik sehingga bagian tersebut dapat memperbanyak diri menjadi tanamanyang seragam dengan induknya. Dalam perbanyakan tanaman secara kultur jaringan perlu diperhatikan beberapa hal, yaitu media kultur, teknik yang digunakan serta bahan tanam yang digunakan harus bersih dari micro organisme dan patogen.

Ektrak biji pinang muda merupakan bahan organik yang mengandung tannin dan mampu menggantikan fungsi bayclin (bahan sintetis), dipakai dalam kegiatan kultur jaringan mengandung markuri serta berbahaya bagi kesehatan. Air kelapa sebagai cadangan makanan yang mengandung vitamin dan zat tumbuh, sehingga dapat menstimulir perkecambahan. Air kelapa mengandung zat atau bahan seperti; vitamin, asam amino, asam nukleat fosfor, dan zat tumbuh auksin dan asam giberelat, yang berfungsi sebagai penstimulir dalam proliferasi jaringan, memperlancar metabolisme dan respirasi (Zulkifli dan Lukmanasari, P. 2017).

\section{BAHAN DAN METODA}

Penelitian dilaksanakan di Laboratorium Bioteknologi Fakultas Pertanian Universitas Islam Riau Pekanbaru selama 6 bulan dari bulan Juni sampai November 2019.

Bahan yang digunakan: Bonggol Pisang Klutuk (Kebun Masyarakat Teratak Buluk, Kabupaten Kampar, Riau), Bayclin, biji pinang muda dan Air kelapa muda. Alat yang digunakan berupa; parang, tembilang, belender, $\mathrm{pH}$ Meter, pisau carter, timbangan analitik, Flow Laminating Cabinet, Autoklaf, camera dan alat tulis. 
Penelitian menggunakan Rancangan Acak Lengkap Faktorial dengan 2: Faktor pertama adalah Ekstrak Biji Pinang muda (P) ada 4 taraf: 0, 10, 20, $30 \%$ dan Faktor kedua adalah Air Kelapa Muda (K) ada 4 taraf : 0, 10, 20, $30 \mathrm{ml} / \mathrm{l}$ larutan, terdapat 16 kombinasi perlakuan dengan 3 ulangan dan setiap unit percobaan terdiri dari 2 botol, setiap botol ditanam 1 eksplan yang dijadikan sampel serta total eksplan keseluruhan 96 botol. Data yang diperoleh kemudian dilakukan Uji Statistik dengan menggunakan Anova, apabila terdapat perbedaan maka dilakukan Uji Lanjut dengan menggunakan Uji Beda Nyata Jujur pada taraf $5 \%$.

Pelaksanaan penelitian meliputi persiapan media MS, persiapan eksplan, Pemasangan Label, Pemberian Perlakuan (Ekstrak Biji Pinang, caranya: Bonggol pisang yang telah dicuci pada tahap pertama dilanjutkan desinfektan dengan mengunakan ekstrak biji pinang yang sudah diblender dengan konsentrasi sesuai perlakuan yang telah ditetapkan, yiatu P0 (kontrol), P1 (10 \% : 100 $\mathrm{g}$ biji pinang diblender dan dicampur air sampai $1000 \mathrm{ml}), \mathrm{P} 2$ (20\% : $200 \mathrm{~g}$ biji pinang diblender dan dicampur air sampai $1000 \mathrm{ml}$ ), P3 (30\% : $300 \mathrm{~g}$ biji pinang diblender dan dicampur air sampai $1000 \mathrm{ml}$ ). Selanjutnya bonggol pisang direndam dalam ekstrak biji pinang dan didiamkan 15 mnit dan kemudian dibersihkan dengan aguades sebanyak 3 kali) dan Air Kelapa Muda, caranya Perlakuan air kelapa muda yang sudah yang sudah disaring di masukkn ke dalam media MS sesuai konsentrasi, yaitu K0 (kontrol), K1(10 ml/liter media), K2 (20 ml/liter media), K3 (30 ml/l media). Pengkulturan Penanaman eksplan dilakukan didalam laminar air flow dengan kondisi yang aseptis. Waktu bekerja, tangan disemprot terlebih dahulu menggunakan alkohol 70\%. Bonggol tanaman Pisang yang sudah disiapkan yang memiliki ukuran seragam dengan ukuran 3-5 cm, lalu diambil dengan menggunakan pinset. Selanjutnya ditanam dalam botol kultur yang sebelumnya telah berisi media MS sesuai perlakuan dengan menggunakan pinset dengan masing - masing botol berisi satu eksplan. Setelah eksplan dimasukkan kedalam botol kultur, kemudian botol diputar diatas api lampu spritus selanjutnya plastik juga dipanaskan diatas api dan botol ditutup kembali dengan menggunakan plastik yang telah dipanaskan, plastik dirapatkan atau ditegangkan dengan tangan dan diikat dengan karet gelang, kemudian bagian plastik yang pinggir botol dirapikan dengan gunting. Setelah itu botol kultur di pindahkan rak-rak kultur diruang inkubasi dan Pemeliharaan dengan menjaga suhu ruangan antara $24^{\circ} \mathrm{C}$ dan diberikan penyinaran dengan lampu neon 20 watt. Agar ruangan kultur tetap steril maka dilakukan pengepelan lantai dan memisahkan eksplan yang terkontaminasi oleh bakteri atau jamur. Ruangan kultur disemprot dengan formalin $0,4 \%$ satu bulan sekali yang berfungsi untuk mensterilkan ruangan.

Parameter yang diamati Persentase Ekplan Hidup, persentase eksplan terkontaminasi, Umur Muncul Tunas, Jumlah Ekplan Bertunas. Semua Pengamatan dilakukan pada akhir penelitian. Data yang diperoleh dianalisis secara statistik dan disajikan dalam bentuk grafik dan tabel.

\section{HASIL DAN PEMBAHASAN}

\section{Persentase Hidup Eksplan (\%)}

Hasil pengamatan terhadap parameter pengamatan persentase eksplan yang hidup, pada perlakuan P2K2 (ekstrak pinang muda 20 $\%$ dan air kelapa muda $20 \mathrm{ml} / \mathrm{l}$ media) memiliki persentase hidup $100 \%$, hal ini diduga pada perlakuan pemberian konsentrasi yang tepat pada eksplan pisang klutuk sehingga dapat mempengaruhi reaksi-reaksi biokimia dan dapat mengubah komposisi di dalam tanaman yang dapat mengakibatkan protoplasma di dalam sel bertambah dan dinding sel akan membesar, proses ini merupakan penyebab terjadinya pertambahan sel yang nantinya pertambahan sel ini akan memunculkan tunas pada tanaman. Hasil pengamatan terhadap, persentase hidup eksplan setelah dilakukan analisis ragam, rerata dapat dilihat pada grafik 1 . 


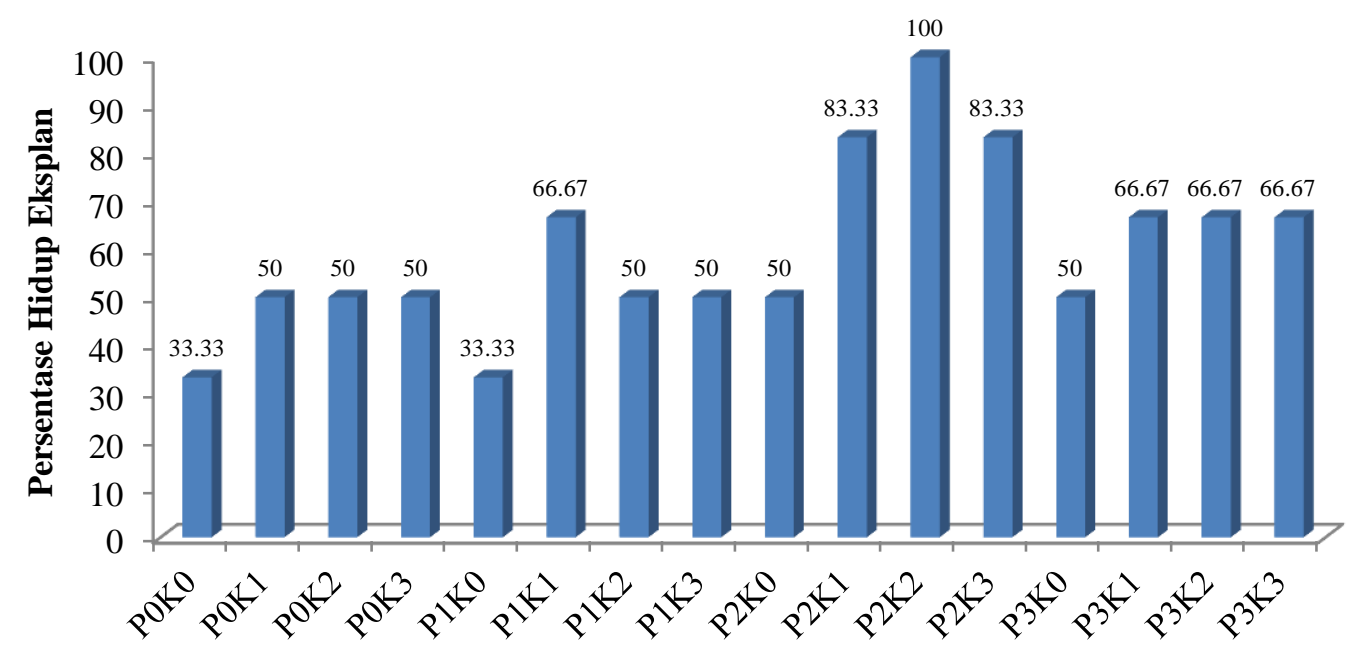

Perlakuan Ekstrak Pinang muda dan Air kelapa muda

\section{Gambar 1. Grafik Persentase Hidup Eksplan}

\section{Persentase Eksplan Terkontaminasi (\%)}

Persentase eksplan terkontaminasi paling sedikit atau terbaik adalah $\mathrm{P} 2 \mathrm{~K} 2$ yaitu $0 \%$ (tidak ada terkontaminasi), hal ini dikarenakan pada perlakuan tersebut sudah mampu merangsang atau mempercepat pertumbuhan tunas dan akar eksplan pisang klutuk. Hasil pengamatan terhadap, persentase eksplan terkontaminasi setelah dilakukan analisis ragam, rerata dapat dilihat pada grafik 2.

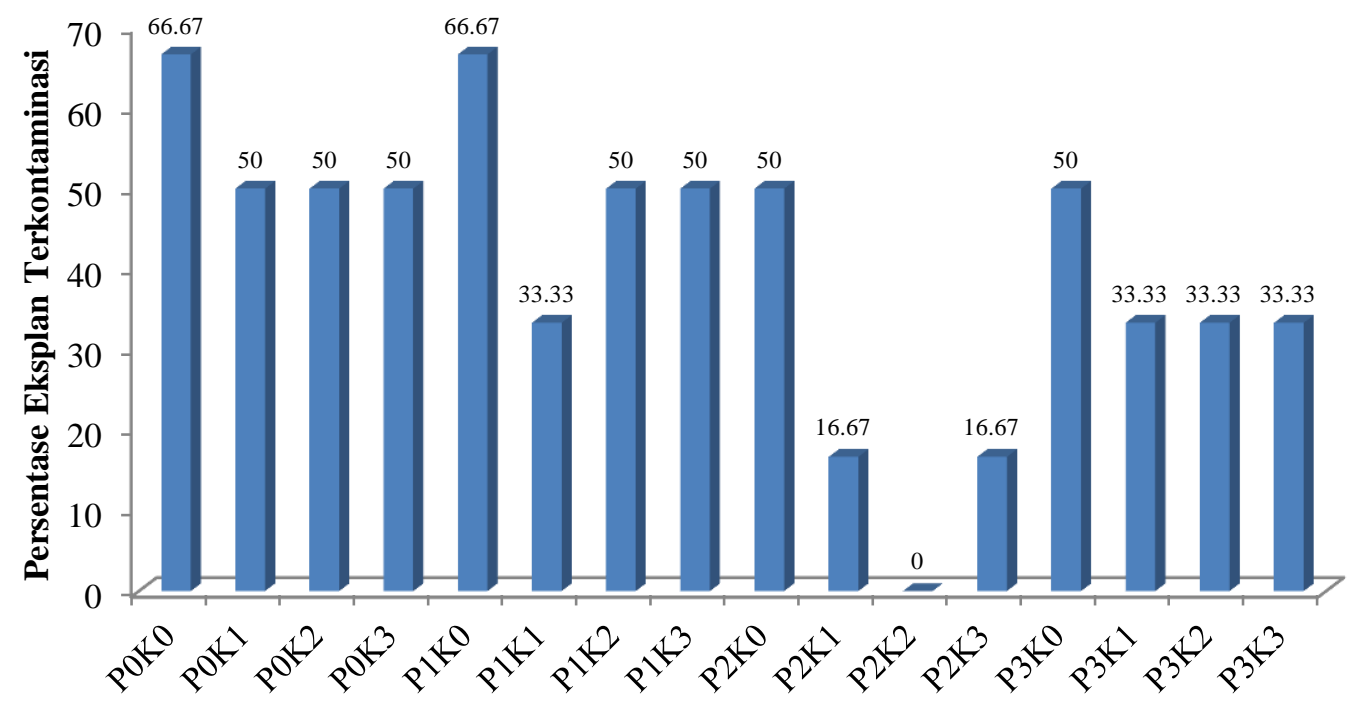

Perlakuan Ekstrak pinang muda dan Air kelapa muda

\section{Gambar 2. Grafik Persentase Eksplan Terkontaminasi}

\section{Umur Muncul Tunas}

Hasil pengamatan terhadap umur muncul tunas, pada perlakuan P2K2 memberikan hasil terbaik, hal ini diduga kombinasi ekstrak pinang $20 \%$ dan air kelapa muda $20 \mathrm{ml} / \mathrm{l}$ larutan dapat memacu morfogenesis dalam pembentukan tunas dalam satu media dan dapat memacu proliferasi tunas karena adanya pengaruh sinergisme antara kedua zat pengatur tumbuh tersebut. Kedua perlakuan ini mempunyai peranan penting dalam menentukan arah diferensiasi sel. Perbanyakan tanaman yang dihasilkan secara kultur jaringan. Semakin cepat pembentukan tunas maka semakin tinggi nutrisi yang diserap oleh eksplan sehingga mempercepat pembentukan eksplan yang membentuk individu baru, semua eksplan masih berada didalam botol yang sumber nutrisinya hanya terdapat didalam media agar tersebut, dan 
nutrisi yang tersedia merupakan faktor utama dalam menunjang perkembangan eksplan untuk membentuk tanaman baru. Hasil pengamatan terhadap umur muncul tunas setelah dilakukan analisis ragam, rerata dapat dilihat pada grafik 3 .

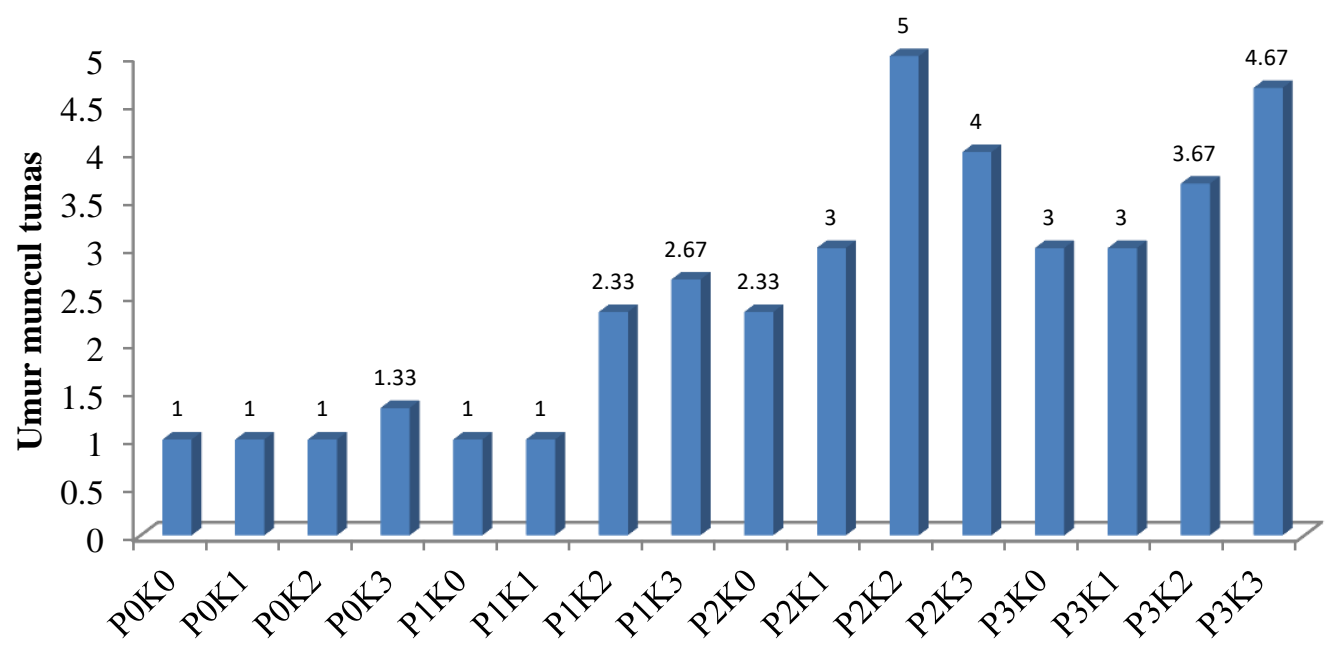

Perlakuan Ekstrak Pinang muda dan Air Kelapa muda

Gambar 3. Grafik Umur Muncul Tunas

\section{Jumlah Tunas}

Jumlah tunas terbanyak pada perlakuan P2K2, hal ini dikarenakan adanya interaksi yang tepat dengan penambahan hormone endogen eksplan dan hormone eksogen. Sitokinin berperan sangat penting dalam pembelahan sel yang apabila di berikan dalam konsentrasi yang sesuai maka akan mempercepat pembelahan sel sehingga memperbanyak jumlah tunas. Hasil pengamatan terhadap jumlah tunas setelah dilakukan analisis ragam, rerata dapat dilihat pada grafik 4 .

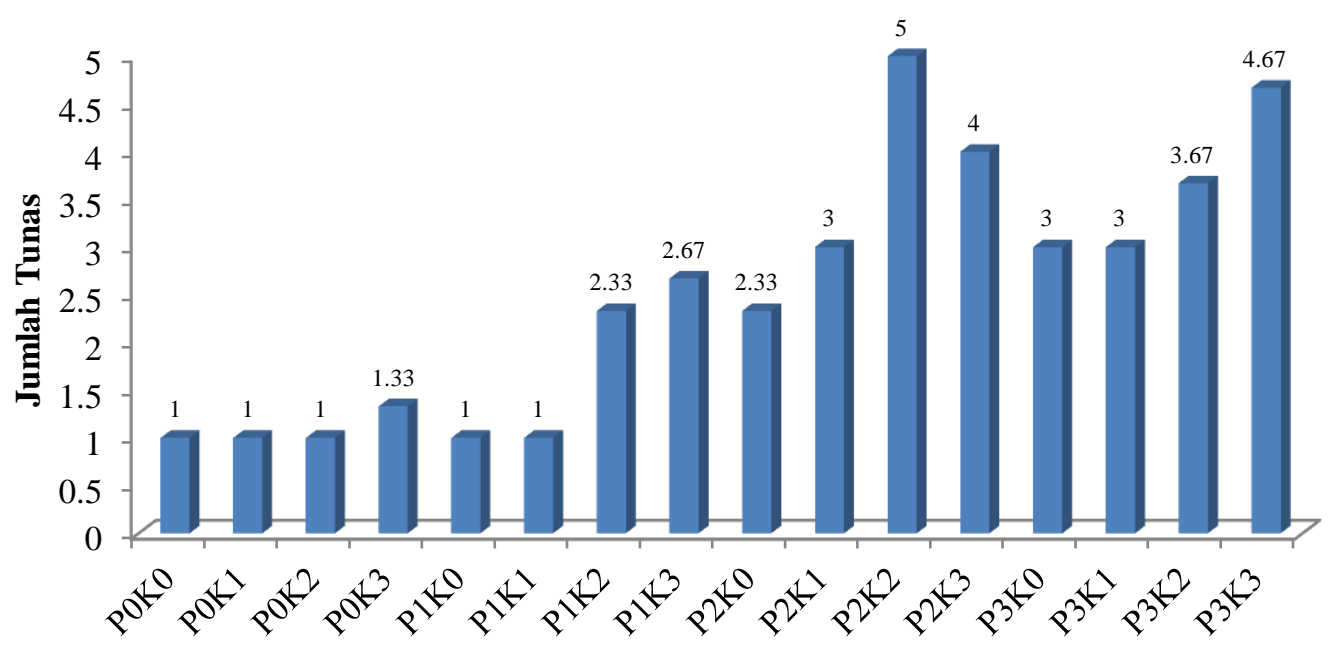

Perlakuan Ekstrak pinang muda dan Air kelapa muda

\section{Gambar 4. Grafik Jumlah Tunas}

Pada kultur jaringan perlu diperhatikan beberapa hal, yaitu media kultur, teknik yang digunakan serta bahan tanam yang digunakan harus bersih dari microorganisme dan pathogen. Terkontaminasi media cukup besar khusus daerah tropis dapat mencapai $95 \%$, dan berbeda daerah dingin hanya $5 \%$, untuk mengatasi tersebut bahan yang digunakan harus desinfektan agar keberhasilan pengkulturan dapat maksimal, dan untuk lebih berhasil harus mengunakan ZPT yang tepat serta tidak menimbulkan efek negative terhadap pemakai maupun lingkungan. Oleh sebab itu dapat digunakan ekstrak pinang yang mengandung tanin memiliki sifat yaitu dapat 
larut dalam air atau alkohol karena tanin banyak mengandung fenol yang memiliki gugus $\mathrm{OH}$, dapat mengikat logam berat, serta adanya zat yang bersifat anti rayap dan jamur (Carter et al, 1978).

Biji buah pinang mengandung alkaloid, seperti arekolin (C8H13NO2), arekolidin, arekain, guvakolin, guvasin dan isoguvasin. Ekstrak etanolik biji buah pinang mengandung tannin terkondensasi, tannin terhidrolisis, flavan, dan senyawa fenolik, asam galat, getah, lignin, minyak menguap dan tidak menguap, serta garam (Wang \& Lee, 1996). Flavanoid merupakan senyawa polar yang umumnya mudah larut dalam pelarut polar seperti etanol, menthanol, butanol, dan aseton (Markham, 1998). Flavanoid merupakan golongan terbesar dari senyawa fenol, senyawa fenol mempunyai sifat efektif menghambat pertumbuhan virus, bakteri dan jamur. Para peneliti lain juga menyatakan pendapat sehubungan dengan mekanisme kerja dari flavonoid dalam menghambat pertumbuhan bakteri, antara lain bahwa flavonoid menyebabkan terjadinya kerusakan permeabilitas dinding sel bakteri (Sabir, 2008). Didukung juga dengan penelitian Mirzoeva et al., (1997) mendapatkan bahwa flavonoid mampu menghambat motilitas bakteri. Tannin tersebar luas dalam tumbuhan berpembuluh, dalam angiospermae terdapat khusus dalam jaringan kayu. Senyawa tannin mampu menghambat pertumbuhan bakteri dengan cara mengkoagulasi protoplasma bakteri. Tannin memiliki peran sebagai antibakteri dengan cara mengikat protein sehingga pembentukan dinding sel akan terhambat. Tannin juga terkandung didalam ekstrak biji Pinang. Mekanisme penghambatan tannin yaitu dengan cara dinding bakteri yang telah lisis akibat senyawa saponin dan flavonoid, sehingga menyebabkan senyawa tannin dapat dengan mudah masuk ke dalam sel bakteri dan mengkoagulasi protoplasma sel bakteri $\mathrm{S}$. aureus dan E. coli. Didukung oleh Santoso (2013) yang menyatakan bahwa semakin tinggi konsentrasi ekstrak, semakin menurun jumlah koloni bakteri yang tumbuh.

Secara umum, zat pengatur tumbuh yang digunakan dalam kultur in-vitro ada tiga kelompok besar, yaitu auksin, sitokinin dan giberelin. Auksin berfungsi untuk merangsang pertumbuhan akar, sitokinin untuk pertumbuhan tunas pucuk, dan giberelin untuk diferensiasi atau perbanyakan fungsi sel.
Sitokinin (BAP) merupakan kelompok hormon tumbuhan yang sangat penting sebagai pemacu pertumbuhan dan morfogenesis yang digunakan dalam kultur jaringan. BAP (Benzyl Amino Purine) adalah ZPT generasi pertama sitokinin sintetik yang berperan dalam memunculkan tunas dan umum digunakan dalam kegiatan kultur in-vitro, hanya saja harganya relatif mahal, diperlukan pengganti berupa bahan organic yang relative murah yaitu air kelapa. Sitokinin alami yang banyak digunakan diantaranya adalah air kelapa. Hasil penelitian menunjukkan bahwa air kelapa kaya potasium (kalium) hingga $17 \%$. Selain itu, air kelapa juga mengandung gula antara 1.7-2.6\% dan protein $0.07-0,55 \%$. Mineral lainnya antara lain natrium (Na), kalsium $(\mathrm{Ca})$, magnesium $(\mathrm{Mg})$, ferum $(\mathrm{Fe})$, cuprum $(\mathrm{Cu})$, fosfor (P) dan sulfur (S) (Anonim, 2012). Air kelapa juga mengandung berbagai macam vitamin seperti asam sitrat, asam nikotinat, asam pantotenal, asam folat, niakin, riboflavin dan thiamin. Air kelapa adalah salah satu bahan alami, didalamnya terkandung hormon seperti sitokinin $5.8 \mathrm{mg} / \mathrm{l}$, auksin $0.07 \mathrm{mg} / \mathrm{l}$ dan giberelin dalam jumlah yang sedikit serta senyawa lain yang dapat menstimulasi pertumbuhan tanaman (Dwijoseputro, 1994).

Menurut Salisbury dan Ross (1995), respon tanaman terhadap sitokinin alami dan berhubungan dengan konsentrasinya, konsentrasi yang tinggi bersifat menghambat pertumbuhan. Air kelapa selain mengandung sitokinin juga mengandung auksin. Hormon sitokinin merangsang pembelahan sel melalui peningkatan laju sintesis protein (Harjadi, 2009). Beberapa diantara protein ini dapat berperan sebagai enzim yang dibutuhkan untuk terjadinya mitosis sedangkan auksin akan memacu pemanjangan sel-sel yang menyebabkan pemanjangan batang. Ketersediaan hormon sitokinin dan auksin yang cukup dalam bahan tanaman memenuhi kebutuhan tanaman sehingga tidak dibutuhkan lagi tambahan hormon eksogen dalam konsentrasi yang tinggi.

Berdasarkan hasil analisis Kristina \& Syahid (2012) dalam satu liter air kelapa tidak hanya mengandung ZPT tetapi juga mengandung mineral lain seperti thiamin, piridoksin dan hara makro (N,P,K). Walaupun air kelapa mengandung ZPT alami yang bersifat termolabil, namun perlakuan autoclave tidak mengurangi aktivitasnya dalam proses pembelahan sel sehingga multiplikasi tunas 
dapat tetap berjalan efektif (Seswita 2010). Matatula (2003) menjelaskan bahwa penambahan air kelapa dalam media tanam dengan kadar yang rendah justru akan membantu proses pertumbuhan vegetatif tanaman karena kandungan $\mathrm{N}$ yang dibutuhkan oleh tanaman cukup. Hal ini menunjukkan bahwa penambahan konsentrasi air kelapa yang berbeda menunjukkan respon tumbuh yang berbeda pula. Air kelapa pada konsentrasi rendah berpengaruh efektif terhadap pertumbuhan tinggi tunas, sedangkan pada konsentrasi tinggi berpengaruh efektif terhadap pertumbuhan jumlah tunas dan jumlah daun.

\section{KESIMPULAN}

Dari hasil penelitian ini dapat disimpulkan bahwa respon ekplan pisang klutuk secara interaksi berpangaruh nyata terhadap kosentrasi ektrak biji pinang muda dan kosentrasi air kelapa muda secara in vitro. Perlakuan terbaik P2K2 (pada ekstrak biji pinang muda $20 \%$ (200 $\mathrm{ml}+800 \mathrm{ml}$ aquades) dan air kelapa muda $20 \mathrm{ml} /$ liter media), dimana persntase hidup $100 \%$, Persentase terkontaminasi $0 \%$, Umur muncul tunas 37,67 hari dan jumlah tunas 5 helai.

\section{DAFTAR PUSTAKA}

Abdurrahman. 2011. Cara Budidaya Tanaman Pisang (Musa spp) Bag. 2. Departemen Kementerian Pertanian Indonesia, Jakarta.

Asnin. 2010. Laporan Hasil Pelaksanaan Kegiatan Laboratorium Kultur Jaringan ( Upt Benih ) Dinas Tanaman Pangan dan Holtikultura Provinsi Riau. Dinas Pertanian Provinsi Riau, Pekanbaru.

Carter, F. L., A. M. Carlo and J. B. Stanley. 1978. Termiticidal Components of Wood Extracts : 7-Methyljuglone from Diospyros virginia. Journal Agriculture Food Chemistry, 26 (4): 869-873.

Dodik dan Lety. 2008. Pemasaran Produk Produk Agroforestry. Institut Pertanian Bogor, Bogor.

Dwijoseputro, D. B. 1994. Pengantar Fisiologi Tumbuhan. PT. Gramedia, Jakarta.

Kristina, N. N. dan F. S. Syahid. 2008. Multiplikasi Tunas, Aklimatisasi dan Analisis Mutu Simplisia Daun Encok (Plumbago zeylanica L.) Asal Kultur In Vitro Periode Panjang. Bul. Littro, 212(2):117-128.
Matatula A. J. 2003. Substitution of MS Medium with Coconut Nater and Gandasil D on Chrysanthemum Tissue Culture. Eugenia, 9 (4): 203-211.

Mirzoeva O. K., R. N. Grishanin, P. C. Calder. 1997. Microbiol Res : Antimicrobial action of propolis and some of its components: the effects on growth, membrane potential, and motility of bacteria. 152: 239 - 46 .

Permathic. 2013. Manfaat buah pisang. Online pada:

http://permathic.blogspot.com/2017/04/g andungan-gizi-dan-manfaat-buah pisang.html. Diakses Tanggal 25 April 2019.

Sabir, A. 2008. In Vitro Antibacterial Activity Of Flavonoids Trigona Sp Propolis Against Streptococcus Mutans. Online pada: http://www.journal.unair.ac.id/file rPDF/DENTJ-383-08.pdf. Diakses Tanggal 02 Januari 2019.

Salisbury, F. B., C. W. Ross. 1995. Fisiologi Tumbuhan Jilid 3. Lukman DR dan Sumarjono, penerjemah. Institut Teknologi Bandung, Bandung.

Santoso, K. R. A. dan A. Hirzi. 2013. Efektivitas Ekstrak Etanol Biji Pinang (Areca catechu Linn.) terhadap Pertumbuhan Bakteri Streptococcus mutans Secara In Vitro. Skripsi (Tidak Dipublikasikan) Program Studi Pendidikan Dokter Gigi Fakultas Kedokteran, Universitas Brawijaya, Malang.

Seswita, D. 2010. Penggunaan Air Kelapa Sebagai Zat Pengatur Tumbuh pada Multiplikasi Tunas Temulawak (Curcuma xanthorrhiza) In Vitro. Jurnal Littri, 16(4): 135-140.

Wang, C. K. dan W. H. Lee. 1996. Separation, characteristics, and biological activities of phenolics in Areca fruit. Journal Agric. Food Chem, 44(8): 2014- 2019.

Zulkifli dan P. Lukmanasari. 2017. Uji Desinfektan dan ZPT pada Media MS terhadap Pertumbuhan Eskplan Tanaman Pisang Klutuk (Musa parasidiaca. L). Lembaga Penelitian Universitas Islam Riau, Pekanbaru. 
